American Journal of Environmental Sciences 8 (1): 5-10, 2012

ISSN 1553-345X

(C) 2012 Science Publications

\title{
Birds as a Tool for Island Habitat Conservation and Management
}

\author{
Pedro Rodrigues and Regina Tristao da Cunha \\ Department of Biology, \\ Research Center in Biodiversity and Genetic Resources, University of the Azores, Portugal
}

\begin{abstract}
Problem statement: The Azores is a archipelago of nine volcanic islands, situated in the middle of the North Atlantic Ocean. Oceanic islands are known hotspots of biodiversity and the Azores, although relatively young (0.3-13 MA), conform to this general pattern. The local avifauna amount to 37 birding species, with two endemic species and 11 endemic subspecies. With an estimated population of 240,000 inhabitants, with increasing needs, most of the natural habitats that support bird populations are under a constant pressure. The use of bird distribution and species richness could be used as a suitable tool for management and would also be effective when applied in other archipelagos. Approach: In the course of the Bionatura project, the Atlantis Tierra 2.0 software provided the storage of biological data from all the islands, including the avifauna, in a $500 \times 500 \mathrm{~m}$ grid. As an outcome, important items for bird conservation and habitat management were achieved for all the species occurring in the archipelago, including species richness. Results: A detailed knowledge of the spatial distribution of the endemic species and sub-species, plus the protected species, is a powerful tool for conservation and management policies in small islands where biodiversity is usually restricted to narrow distributions. Conclusion: The results defined an area of 39, $273 \mathrm{~h}$ (16.8\% of Azores total area); providing an ideal area for conservation of suitable habitats for bird's species in the Azores.
\end{abstract}

Key words: Savage birds, habitat conservation and management, Azores islands, Special Protection Areas (SPA), volcanic islands, North Atlantic Ocean, oceanic islands, Atlantis Tierra

\section{INTRODUCTION}

According to the IUCN 2009, over 1200 (12\%) of the world's bird species are considered threatened with extinction (i.e., in the categories of Critically Endangered, Endangered, Vulnerable and Extinct in the Wild). An additional 838 species are considered Near Threatened, giving a total of 2065 species that are urgent priorities for conservation action.

Only $17 \%$ of the world"s bird species are found on islands (Johnson and Stattersfield, 1990). However islands hold disproportionately high numbers of threatened species, supporting over half of globally threatened species because birds inhabiting islands are particularly susceptible to human influences owing to an isolated evolutionary history (Bird Life International, 2004).

Oceanic islands are unique geological and biological units. In the majority of cases, they remained isolated from human influence until recently and have been the stage for many of the recent reported extinctions (Walter and Kenton, 1989; Bibby, 1994; Pimm et al., 1994; Steadman, 1995; Steadman and Martin, 2003; Steadman, 2006). Indeed, the arrival of humans on oceanic islands has precipitated a wave of extinctions among the islands' native birds (Blackburn et al., 2004).

Compared with continents, greater rates of natural extinction might be expected among islands because they are relatively small areas with a large percentage of endemic species, their populations and ranges are smaller and species are therefore more vulnerable to any catastrophic event, habitat destruction and fragmentation, invasive species. (Paulay, 1994; Quammen, 1997; Biber, 2002; Yrjo, 2002; Newton, 2003; Duncan and Blackburn, 2007; Whittaker and Fernández-Palacios, 2007).

Maps of species distribution or habitat suitability are required for many aspects of environmental research, resource management and conservation planning. These include biodiversity assessment, reserve design, habitat management and restoration, species and habitat conservation plans and predicting the effects of environmental changes on species and ecosystems (Franklin and Miller, 2009).

The present study was developed on the oceanic islands of the Azores, one of the archipelagos belonging to the biogeographical region of Macaronesia, together

Corresponding Author: Department of Biology, Research Center in Biodiversity and Genetic Resources, University of the Azores, Portugal 
with Madeira, Canary Islands and Cape Verde. Due to its isolated location in the heart of the North Atlantic Ocean, $1500 \mathrm{~km}$ from Europe and $1900 \mathrm{~km}$ from America, the Azores archipelago presents a small diversity of native species and birds are no exception.

The Azores were uninhabited by humans until 1433 when they were colonized by the Portuguese. Human settlements and land use had different levels of impact on the islands but the intensive use of the forest for wood and pasture and of the coast and its resources, have been common factors affecting bird distribution since then.

Actually, in these volcanic oceanic islands 37 species of birds breed regularly but their importance at the species and population levels are unique. Among them, one can list two endemic birds, the Azores bullfinch and the Monteiro's storm petrel (also considered as two of the most endangered species in the world); thirteen endemic sub-species from six orders; and some of Europe's most important populations of marine bird species, such as Cory's and Macaronesian shearwaters, Madeiran storm petrels and Roseate and common terns (Bannerman et al., 1966; Bibby et al., 1992; Nevo et al., 1993; Ramos, 1995; Monteiro et al., 1996; Monteiro and Furness, 1998; Monteiro et al., 1999; Dickens and Neves, 2005; Clarke, 2006; Dietzen et al., 2006; Bolton et al., 2008).

In the Azores, the first inventory of the important bird areas in Europe listed seven sites, recognizing the poor knowledge at that time of the distribution of the breeding species of the archipelago (Grimmet and Jones, 1989). The first legal action towards the conservation of wild birds was the adoption of the Birds Directive in 1990 in the Azores, designating a total of 15 Special Protection Areas (SPA) (Table 1) and it made clear that the actual SPA of the region covered only $21 \%$ of the needed area for bird protection (Groz and Pereira, 2005).

Table 1: Special protected areas of the Azores (Anon, 1991)

\begin{tabular}{llr}
\hline Island & Place & Area $(\mathrm{H})$ \\
\hline Corvo & Coast and caldeirão & 642 \\
Flores & S and SW Coast & 230 \\
& NE coast & 130 \\
Faial & Caldeira and capelinhos & 2076 \\
Pico & Lages do pico & 29 \\
& Ponta da ilha & 324 \\
& Furnas de santo António & 23 \\
& Central area & 5832 \\
São jorge & Topo islet and adjacent coast & 346 \\
Graciosa & Baixo islet & 30 \\
& Praia islet & 12 \\
Terceira & Ponta das contendas & 93 \\
& Cabras islets & 28 \\
São miguel & Pico da vara and guilherme stream & 1982 \\
Santa maria & Vila islet and adjacent coast & 48 \\
& Total area & 11825 \\
\hline
\end{tabular}

The aims of this study were: (i) To propose priority areas for conservation of important habitats for birds and (ii) To propose a revision of their SPA, using maps of species distribution based on scientific publications, allowing correct management and providing a methodology that could be applied consistently to any other ocean archipelagos or islands.

\section{MATERIALS AND METHODS}

Study area: The Azores, a Portuguese Autonomous Region, is an archipelago of nine volcanic islands situated in the mid-north Atlantic Ocean (between $36^{\circ} \mathrm{C} 55^{\prime}$ and $39^{\circ} \mathrm{C} 43^{\prime} \mathrm{N}$ and $25^{\circ} \mathrm{C} 01$; and $31^{\circ} \mathrm{C} 07$; W), $1500 \mathrm{~km}$ from Europe and $1900 \mathrm{~km}$ from North America (Fig. 1).

The discovery of the archipelago took place in 1427. At the time, there were reports of vast colonies of birds, particularly seabirds. The settlement of the islands, 12 years after the discovery, brought some changes, with species that used to breed abundantly in the archipelago decreasing drastically. This decrease was caused by their use as food and oil sources for the human population, by the introduction of predators and by many changes in habitat. Even a species of pigeon, reported to exist in abundance at the time of the colonisation, went extinct (Rodrigues and Michielsen, 2010). The majorities of the 260,000 inhabitants live and work around the coast resulting in significant development pressure on the environment. In the last 20 years, this trend has even increased considerably. The narrow littoral fringe of the 216

Azores islands are one of the few land areas that offers potential for settlement and Azoreans are strongly dependent upon the sea for income, communication and trade. This explains the coastal location of major commercial facilities and employment opportunities, together with economic activities and population (Andrade et al., 2006).

Study species: In the Azores, 37 bird species breed regularly (Table 2): Two are endemic to the Azores, two are endemic to the Micronesia, ten are Azorean endemic subspecies and eight of them are endangered species protected by the European Council Directive 79/409/EEC, of April 2, 1979, on the conservation of wild birds.

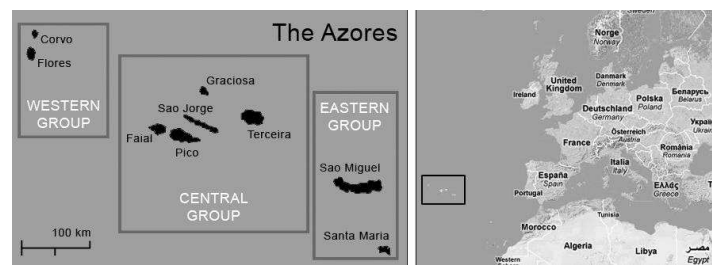

Fig. 1: Location of the archipelago of the azores 
Am. J. Environ. Sci., 8 (1): 5-10, 2012

Table 2: List of breeding birds of the Azores. N: Native; I: Introduced; N/I: Native or Introduced; EA: Endemic to the Azores; EM: Endemic to the Micronesia; BD-in annex A of Bird Directive (based on Rodrigues et al., 2010)

\begin{tabular}{|c|c|}
\hline Species & Status \\
\hline Anas platyrhynchos platyrhynchos (Linnaeus, 1758) & $\mathrm{N}$ \\
\hline Anas rubripes (Brewster, 1902) & $\mathrm{N}$ \\
\hline Alectoris rufa (Seoane, 1894) & N/I \\
\hline Coturnix coturnix conturbans (Hartert, 1917) & $\mathrm{N} / \mathrm{I}$ \\
\hline Oceanodroma castro (Harcourt, 1851) & N BD \\
\hline Oceanodroma monteiroi (Bolton et al., 2008) & NES \\
\hline Bulweria bulwerii (Jardine and Selby, 1828) & N BD \\
\hline Calonectris diomedea borealis (Cory, 1881) & N BD \\
\hline Puffinus baroli (Bonaparte, 1857) & N EM BD \\
\hline Puffinus puffinus (Brünnich, 1764) & $\mathrm{N}$ \\
\hline Buteo buteo rothschildi (Swann, 1919) & N ESS \\
\hline Fulica atra atra (Linnaeus, 1758) & $\mathrm{N}$ \\
\hline Gallinula chloropus (Linnaeus, 1758) & $\mathrm{N}$ \\
\hline Charadrius alexandrinus (Linnaeus, 1758) & $\mathrm{N}$ \\
\hline Larus michahellis atlantis (Dwight, 1922) & N ESS \\
\hline Gallinago gallinago (Linnaeus, 1758) & $\mathrm{N}$ \\
\hline Scolopax rusticola (Linnaeus, 1758) & $\mathrm{N}$ \\
\hline Onychoprion fuscatus (Linnaeus, 1766) & $\mathrm{N}$ \\
\hline Sterna dougallii (Montagu, 1813) & N BD \\
\hline Sterna hirundo (Linnaeus, 1758) & N BD \\
\hline Columba livia (Gmelin, 1769) & $\mathrm{N}$ \\
\hline Columba palumbus azorica (Hartert, 1905) & N ESS BD \\
\hline Psittacula krameri (Scopoli, 1769) & $\mathrm{I}$ \\
\hline Asio otus otus (Linnaeus, 1758) & $\mathrm{N}$ \\
\hline Estrilda astrild (Linnaeus, 1758) & I \\
\hline Carduelis carduelis parva (Tschusi, 1901) & I \\
\hline Carduelis chloris aurantiiventris (Cabanis, 1851) & $\mathrm{I}$ \\
\hline Fringilla coelebs moreletti (Pucheran, 1859) & N ESS \\
\hline Pyrrhula murina (Godman, 1866) & N ES BD \\
\hline Serinus canaria (Linnaeus, 1758) & N EM \\
\hline Motacilla cinerea patriciae (Vaurie, 1957) & N ESS \\
\hline Passer domesticus (Linnaeus, 1758) & I \\
\hline Sturnus vulgaris granti (Hartert, 1903) & N ESS \\
\hline Regulus regulus azoricus (Seebohm, 1883) & N ESS \\
\hline Regulus regulus inermis (Murphy and Chapin, 1929) & N ESS \\
\hline Regulus regulus sanctae-mariae (Vaurie, 1954) & N ESS \\
\hline Sylvia atricapilla gularis (Alexander, 1898) & $\mathrm{N}$ \\
\hline Erithacus rubecula rubecula (Linnaeus, 1758) & $\mathrm{N}$ \\
\hline Turdus merula azorensis (Hartert, 1905) & N ESS \\
\hline
\end{tabular}

This directive seeks to protect, manage and regulate all bird species naturally living in the wild within the European territory, including their habitats (http://europa.eu/legislation_summaries/environment/na ture_and_biodiversity/128046_en.htm).

Data analysis: Since 1998, the government of the Canary Islands developed a biodiversity project called BIOTA (Zamora and Esquivel, 2004), which consists of a visual basic software, called ATLANTIS Tierra 2.0, for biodiversity data storage. This software has several important tools, such as for taxonomic and conservation management, that allow the calculation of species richness, their rarity or complimentarily in all $500 \times 500$ $\mathrm{m}$ cells of a special area (Borges et al., 2010).

All of the existent data and publications about the species in the Azores were compiled by the project BIONATURA-Data Base for Azorean Biodiversity (http://www.azoresbioportal.angra.uac.pt/index.php?lan $\mathrm{g}=$ en) and introduced on the ATLANTIS Tierra 2.0, where individual island maps, with the most appropriate areas to preserve bird species and their habitats, were constructed based on species richness.

\section{RESULTS}

The results (Fig. 2), indicate that the ideal area to preserve the most important habitats for the Azorean Avifauna (BA) is some $39273 \mathrm{~h}$, which corresponds to $16.8 \%$ of the total area of the Azores.

The island with most BA was São Miguel, the biggest island in the archipelago $\left(745 \mathrm{~km}^{2}\right)$, but it is Corvo, the smallest one $\left(17 \mathrm{~km}^{2}\right)$, has the major percentage of BA in relation to the island Total Area (TA). Graciosa is the island with minor BA and TA.

\section{DISCUSSION}

The definition of the most appropriate areas to preserve the habitats of savage birds, based on species richness, represents a useful tool for species conservation planning and for management decision, not only for the species per si, but also for their habitats. This method takes into account all the species present in a given area, even the ones with lowest effectives. Species with a very restricted area of occupancy are obviously limited in the number of individuals they can maintain. This relation has been long known (Lawton, 2000) and further emphasizes the need to protect these "double rare" species, such as Pyrrhula murina, which is restricted to a small-forested area in the eastern part of São Miguel Island (Ramos, 1995). Species that are only able to survive in a single habitat type, which is a common situation for rare species, present all forms of rarity including distribution, abundance and habitat (Rabinowitz, 1981).

In this study, the maps in Fig. 2 revealed three different types of habitat that should be protected due to their importance to birds. These comprise: (i) The coastal zone, due to marine birds and their important ecological role on ocean islands; (ii) Forests, mainly of endemic type, due to their importance for the endemic land birds; and (iii) River basins and lakes, due to their importance to aquatic birds and to birds in general (Stone et al., 1995; Monteiro et al., 1999; Rodrigues and Michielsen, 2010).

We propose a total area of (39 $273 \mathrm{~h} \pm 16.8 \%$ of the total area of the Azores), three times larger than the actual SPA area $(11825 \mathrm{~h} \pm 5 \%$ of the total area of the Azores). Some islands, such as Corvo and Faial, have all the proposed areas under protection by the Bird Directive. Pico already has $88 \%$, but the rest of the islands need an urgent revision of their SPA, in order to include new areas in São Miguel (18\%), Flores (10\%), Graciosa (8\%), São Jorge (5\%), Santa Maria (3\%) and Terceira (2\%). 


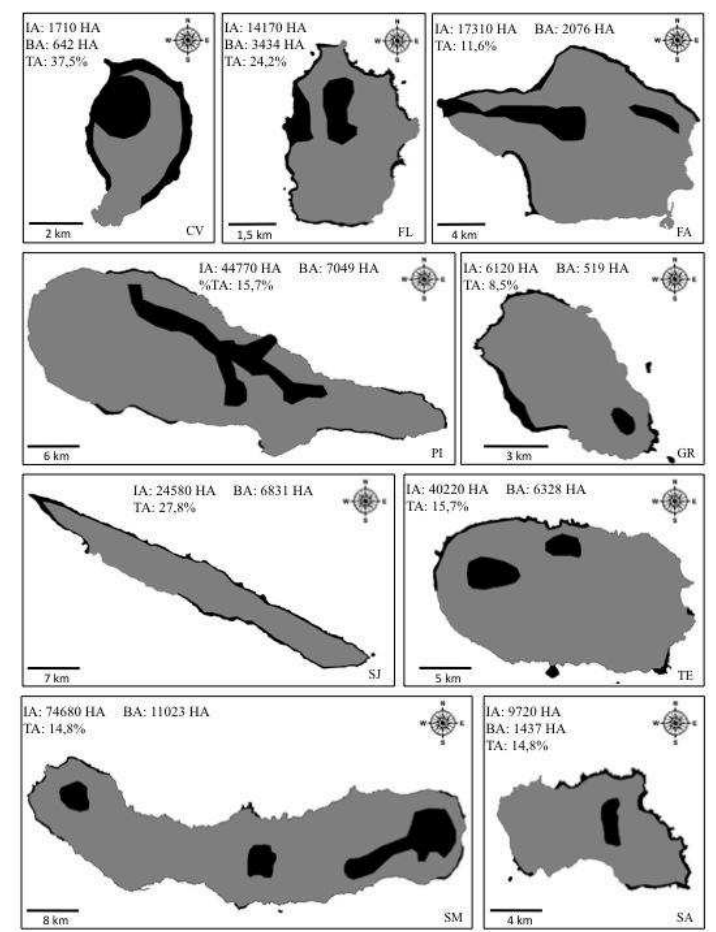

Fig. 2: Most appropriate areas to preserve the habitats of the Azorean bird species (dark areas). IAIsland total Area in hectares; BA-Most appropriate areas to preserve Azorean Avifauna, in hectares; TA-Total percentage of BA in IA; CV-Corvo; FL-Flores

The conservation of island birds is a daunting and expensive task that may require managers to simultaneously address habitat loss, exotic species and disease. More management attention is needed to stabilize or reverse the decline of the Azorean species. High levels of endemism on islands also justify an intensive recovery effort (Restani and Marzluff, 2002).

\section{CONCLUSION}

The results of this study should be applied to the management and conservation planning of the Azores islands, since the definition of the most appropriate areas to preserve wild birds' habitats is an effective way of identifying conservation priorities. These areas are key sites for bird conservation. Their relatively small size allows, effectivelly, for the conservation and management of the biological resourses they enclose. Their importance was already recognized as some are part of a protected-area network. This model could be used as a functional tool for biodiversity assessments, reserve design, habitat management and restoration, as well as, species and habitat conservation plans, not only in the Azores but also in other small archipelagos.

\section{ACKNOWLEDGMENT}

The researchers would like to express their gratitude to Direcção Regional do Ambiente e do Mar for the financial support to the BIONATURA Data base, to the Director Regional da Ciência e Técnologia for the support to the presentation of this study on the first International Conference on Environmental Pollution, Restoration and Management, in Ho Chi Minh City, Vietnam.

\section{REFERENCES}

Andrade, C., P. Borges and M.C. Freitas, 2006. Historical tsunami in the Azores archipelago (Portugal). J. Volcanol. Geoth. Res., 156: 172-185. DOI: 10.1016/j.jvolgeores.2006.03.014,

Anon, 1991. Zonas de Proteccao Especial. Direccao Regional do Ambiente (Acores), Horta.

Bannerman, D.A. and W.M. Bannerman, D.M ReidHenry, 1966. Birds of the Atlantic Islands: A history of the birds of the Azores. Oliver and Boyd. London, ISBN: 0050018027

Bibby, C.J., 1994. Estimating extinction rates: Sir Joseph Banks anniversary meeting. Philos. T. Roy. Soc. B., 344: 35-40.

Bibby, C.J., T.D. Charlton and J. Ramos, 1992. Studies of west paleartic birds Azores bullfinch. Brit. Birds, 85: 677-680.

Biber, E., 2002. Patterns of endemic extinctions among island bird species. Ecography, 25: 661-676. DOI: 10.1034/j.1600-0587.2002.t01-1-250603.x

Bird Life International, 2004. Threatened Birds of the World: 2004. CD-ROM. Bird Life International, Cambridge, UK. Cambridge, ISBN: 0946888515 9780946888511

Blackburn, T.M., P. Cassey, R.P. Duncan, K.L. Evans and K.J. Gaston, 2004. avian extinction and mammalian introductions on oceanic islands. Science, 305: 1955-1958. DOI: 10.1126/science. 1101617

Bolton, M., A.L. Smith, E. Gómez-Díaz, V.L. Friesen and R. Medeiros et al., 2008. Monteiro's stormpetrel oceanodroma monteiroi: A new species from the Azores. Ibis, 150: 717-727.

Borges, P.A.V., A. Costa, R. Cunha, R. Gabriel and V. Gonçalves et al., 2010. A list of the terrestrial and marine biota from the Azores. Princípia, Cascais.

Clarke, T., 2006. Birds of the Atlantic Islands: Canary Islands, Madeira, Azores, Cape Verde. Christopher Helm. pp: 368. 
Dickens, M. and V.C. Neves, 2005. Post-breeding density and habitat preferences of the azores woodpigeon, columba palumbus azorica: An interisland comparison. Arquipelago. Life Marine Sci., 22A: 61-69.

Dietzen, C., C. Voigt, M. Wink, M. Gahr and S. Leitner, 2006. Phylogeography of island canary (Serinus canaria) populations. J. Ornithol., 147: 485-494. DOI: 10.1007/s10336-005-0044-2

Duncan, R.P. and T.M. Blackburn, 2007. Causes of extinction in island birds. Anim. Conserv., 10: 149150. DOI: 10.1111/j.1469-1795.2007.00110.x

Franklin, J. and J.A. Miller, 2009. Mapping species distributions. Spatial inference and prediction. 1st Ed. Cambridge University Press, UK. ISBN: 9780521876353

Grimmet, R.F.A. and T.A. Jones, 1989. Important bird areas in Europe/compiled by R.F.A. Grimmett and T.A. Jones Cambridge, UK. pp: 218.

Groz, P.M. and J.C. Pereira, 2005. Invasive alien species as a threat to seabird populations: an account of habitat restoration on Ilhéu da Praia (Graciosa, Azores) special protection area. Airo, 15: 3-9.

Johnson, T.H. and A.J. Stattersfield, 1990. A global review of island endemic birds. Ibis, 132: 167-180. DOI: 10.1111/j.1474-919X.1990.tb01036.x

Lawton, J.H., 2000. Community ecology in a changing world. International Ecology Institute, Oldendorf/ Luhe, Germany.

Monteiro, L.R. and R.W. Furness, 1998. Speciation through temporal segregation of madeiran storm petrel (Oceanodroma castro) populations in the Azores? Philos. T. Roy. Soc. B., 353: 945-953. DOI: $10.1098 /$ rstb.1998.0259

Monteiro, L.R., J.A. Ramos and R.W. Furness, 1996. Past and present status and conservation of the seabirds breeding in the Azores archipelago. Biol. Conserv., 78: 319-328. DOI: 10.1016/S00063207(96)00037-7

Monteiro, L.R., J.A. Ramos, J.C. Pereira, P.R. Monteiro and R.S. Feio et al., 1999. Status and distribution of Fea's Petrel, Bulwer's Petrel, Manx Shearwater, Little Shearwater and Band-rumped Storm-Petrel in the Azores Archipelago. Waterbirds, 22: 358-366.

Nevo, D.A.J., E.K. Dunn, F.M. Medeiros, G. Le Grand and P. Akers et al., 1993. The status of Roseate Terns Sterna dougallii and Common Terns Sterna hirundo in the Azores. Seabird, 15: 30-37.

Newton, I., 2003. Speciation and biogeography of birds. Academic Press, London, UK, pp: 638.
Paulay, G., 1994. Biodiversity on oceanic islands: its origin and extinction. Am. Zool., 668: 134-144. DOI: $10.1093 / \mathrm{icb} / 34.1 .134$

Pimm, S.L., M.P. Moulton, L.J. Justice, N.J. Collar and D.M.J.S. Bowman et al., 1994. Bird Extinctions in the Central Pacific. Philos. T. Roy. Soc. B., 344: 27-33. DOI: $10.1098 /$ rstb.1994.0047

Quammen, D., 1997. The song of the dodo: island biogeography in an age of extinctions. 1st (Ed.). Simon and Schuster. New York, ISBN: 0684827123

Rabinowitz, D., 1981. Seven Forms of Rarity. In: Synge, H., 1981. The Biological Aspects of Rare Plant Conservation. 1st Edn., Wiley, Chichester, UK., pp: 558.

Ramos, J.A., 1995. The diet of the azores bullfinch Pyrrhula murina and floristic variation within its range. Biol. Conserv., 71: 237-249. DOI: 10.1016/0006-3207(94)00033-M

Restani, M. And J.M. Marzluff, 2002. Funding extinction? Biological needs in the allocation of resources to endangered species recovery. Bioscience, 52: 169-177. DOI: 10.1641/0006-3568

Rodrigues, P. and G. Michielsen, 2010. Birdwatching in the Azores. Artes e Letras. Ponta Delgada.

Rodrigues, P., J. Bried, S. Rodebrand and R. Cunha, 2010. AVES. In: A List of the Terrestrial and Marine Biota from the Azores, Borges, P.A.V., A. Costa, R. Cunha, R. Gabriel and V. Gonçalves et al., (Eds.). Principia, Cascais.

Steadman, D.W. and P.S. Martin, 2003. The late quaternary extinction and future resurrection of birds on Pacific Islands. Earth. Sci. Rev., 61: 133147. DOI: 10.1016/S0012-8252(02)00116-2,

Steadman, D.W., 1995, Prehistoric extinctions of Pacific island birds: Biodiversity meets zooarchaeology. Science, 267: 1123-1131. DOI: 10.1126/science.267.5201.1123

Steadman, D.W., 2006. Extinction and Biogeography of Tropical Pacific Birds. University of Chicago Press, Chicago, ISBN-10: 0226771423, pp: 594.

Stone, C.J., A. Webb, C. Barton, N. Ratcliffe and T.C. Reed et al., 1995. An atlas of seabird distribution in north-west European waters. Joint Nature Conservation Committee, Peterborough. ISBN: 873701942.

Walter, R.V. and M.R. Kenton, 1989. Keeping Options Alive: The Scientific Basis for Conserving Biodiversity. World Resources Institute. pp: 136. ISBN-0-915825-41-4 
Whittaker, R.J. and J.M. Fernandez-Palacios, 2007. Island Biogeography. Ecology, Evolution and Conservation. 2nd Edn., Oxford University Press, Oxford, ISBN-10: 0198566115, pp: 401.

Yrjo, H., 2002. A conceptual genealogy of fragmentation research: from island biogeography to landscape ecology. Ecol. Appl., 12: 321-334. DOI: 10.1890/1051-0761
Zamora, I.I., J.L.M. Esquivel, 2004. Lista de Especies Silvestres de Canarias: Hongos, Plantas y Animales Terrestres. 1st Edn., Consejería de Medio Ambiente y Ordenación Territorial del Gobierno de Canarias, USA., ISBN-10: 8489729239, pp: 499. 